\title{
STRATEGI BIDAN DALAM MEMBERIKAN PERAWATAN KEHAMILAN DAN PERSALINAN DI MASYARAKAT BADUY DALAM DESA KANEKES KAB.LEBAK TAHUN 2013
}

\author{
Yayah Rokayah \\ Korespondensi : yah.chikal@gmail.com
}

\begin{abstract}
Abstrak
Tingginya AKI merupakan salah satu indikasi lemahnya perlindungan terhadap hak reproduksi perempuan yang memiliki kaitan dengan perawatan kehamilan dan persalinan. Jumlah kematian ibu di Baduy tahun 2009-2010 berjumlah 2 orang, penyebab kematian tersebut erat hubungannya dengan sosial budaya seperti kebiasaan, kepercayaan, sikap dan prilaku masyarakat terhadap perawatan kehamilan dan persalinan sehingga mengakibatkan kematian pada ibu. Metode yang digunakan adalah kualitatif, subyek penelitian yaitu bidan desa dan PTT yang ditugaskan di Baduy Dalam, pengumpulan data melalui indept interview. Analisis data menggunakan analisis isi dengan triangulasi kepada ibu hamil, ibu bersalin, tokoh masyarakat dan paraji. Hasil penelitian pada Baduy Dalam dalam perawatan kehamilan dan persalinan masih dilakukan secara tradisional. Norma penanganan masalah pada kehamilan dan persalinan yaitu meminta bantuan ke paraji, dukun pengobatan, tokoh masyarakat, bila dirujuk tidak boleh memakai kendaraan. Yang melanggar akan dihukum selama 40 hari. Tidak ada sarana kesehatan karena dilarang oleh adat setempat. strategi yang dilakukan bidan dalam memberikan informasi pelayanan perawatan kehamilan dan persalinan di masyarakat Baduy Dalam pertama yaitu melakukan pendekatan kepada tokoh masyarakat,menjalin kemitraan bidan dengan paraji yang ada, mendirikan program imah pangubaran pusat informasi Baduy tanpa menghilangkan ciri khas Baduy nya,menjadikan posyandu yang diminati dan dipercaya sebagai tempat pelayanan kesehatan yang efektif dan efesien tanpa menghilangkan ciri khas Baduynya,melakukan kunjungan rumah,petugas kesehatan/bidan harus tinggal menetap di daerah Baduy, bidan bisa menerima dan menghormati budaya mereka apa adanyawaktu pelaksanaan disesuaikan dengan jadwal pelayanan yang sudah disepakati oleh tokoh masyarakat, dalam memberikan informasi media yang digunakan adalah lembar balik, alat peraga sesuai yang diperlukan dan memakai bahasa yang bisa dipahami oleh masyarakat Baduy Dalam yaitubahasa sunda.Untuk memudahkanjangkauan pelayanan kesehatan masyarakat Baduy Dalam hendaknya di bangun sarana rumah tunggu untuk pelayanan perawatan kehamilan dan pertolongan persalinan yang dilengkapi peralatan kesehatan tanpa menghilangkan ciri khas dari budaya Baduynya. Sebelum menugaskan petugas kesehatan hendaknya puskesmas setempat perlu memberi penambahan pengetahuan kepada tenaga kesehatan yang akan bertugas di Baduy terkait budaya setempat.
\end{abstract}

Kata Kunci: Bidan, Kehamilan, Persalinan, Masyarakat Baduy

*Poltekkes Kemenkes Banten 


\begin{abstract}
High maternal mortality rate is one indication of the lack of protection for women's reproductive rights are linked to pregnancy and delivery care. The number of maternal deaths in Baduy in 2009-2010 amounted to 2, the cause of death is closely related to social culture such as customs, beliefs, and attitudes of society to care during pregnancy and childbirth resulting in death of the mother. The method used is a qualitative study subjects that midwives and PTT assigned in Baduy Dalam, data collection through indept interview. Analysis of data using content analysis with triangulation to pregnant women, maternity, community leaders and paraji.Results of research on the Baduy Dalam in care during pregnancy and childbirth is still done traditionally. Norma handling of problems in pregnancy and childbirth are asking for help to paraji, quack medicine, public figures, when referenced should not be put on the vehicle. Violators will be punished for 40 days. There are no health facilities because it is prohibited by local custom. strategies that midwives in providing information on care services during pregnancy and childbirth in Baduy In the first one is to approach community leaders, establish partnerships midwife with paraji existing, established the program imah pangubaran information center Baduy without losing the characteristic Bedouin her, making posyandu interest and believed to be the health services effectively and efficiently without losing the characteristic Baduynya, home visits, health workers / midwife should be settled in the area Baduy, a midwife can accept and respect their culture what their implementation time adapted to the service schedule that has been agreed upon by community leaders, in providing information media used is flipcharts, props as needed, and use language that can be understood by people Baduy Dalam is Sundanese. To facilitate the reach of public health services should be built Baduy Dalam home means waiting for ministry pregnancy care and childbirth assistance which are equipped with medical equipment without removing the hallmark of culture Baduynya. Before assigning health workers should be a local clinic should provide additional knowledge to health professionals who will be on duty at the local Bedouin culture related.
\end{abstract}

Jurnal Medikes, Volume 3, edisi 1, April 2016 


\section{Pendahuluan}

Permasalahan Kesehatan
reproduksi bukan hanya sekedar
masalah kesehatan semata melainkan
merupakan bagian dari keseluruhan
kehidupan manusia, di Indonesia
pelayanan kesehatan reproduksi
khususnya tentang perawatan

kehamilan dan persalinan masih memerlukan perhatian yang serius (Amri, 2002).Dalam laporan Milennium Development Goals tahun 2007/2008 menyebutkan, setiap tahun sekitar 18.000 perempuan di Indonesia meninggal akibat dari komplikasi kehamilan dan persalinan dan sebanyak $60 \%$ persalinan di indonesia dilakukan dirumah (Depkes RI, 2005).

\section{Masalah perawatan}

kehamilan dan persalinan bisa dipengaruhi oleh tradisi budaya daerah masing-masing yang di lakukan secara turun temurun, dimana budaya bagi masyarakat adalah suatu hal yang penting, bahkan dipercaya dan menjadi pegangan hidup oleh masyarakat (Soemardjan, 2001).
Didalam

masyarakat sederhana, kebiasaan hidup dan adat istiadat dibentuk untuk mempertahankan hidup diri sendiri dan kelangsungan hidup mereka, dimana berbagai kebiasaan dikaitkan dengan perawatan kehamilan dan perawatan persalinan yang bertujuan supaya kesehatan ibu hamil dan bersalin selamat dan sehat. Hal ini disebabkan hubungan antara budaya dan kesehatan sangatlah erat, dimana suatu masyarakat desa yang sederhana dapat bertahan dengan cara pengobatan tertentu sesuai dengan tradisi mereka, karena kebudayaan atau kultur dapat membentuk kebiasaan dan respon terhadap kesehatan dan penyakit dalam masyarakat tanpa memandang tingkatannya (Koentjaraningrat, 2001).

Menurut Hasil Survai Demografi Kesehatan Indonesia (SDKI), AKI di Indonesia pada tahun 2007 adalah 228 per 100.000 kelahiran hidup, sementara data terakhir AKI di Indonesia tahun 2010 adalah 208 per 100.000 Kelahiran hidup, angka tersebut 
menunjukan bahwa penurunan angka kematian ibu di Indonesia masih jauh dari yang di harapkan untuk dapat mencapai target $M D G$ 'S yaitu 102 per 100.000 kelahiran hidup di tahun 2015 (Depkes RI, 2010).

\section{Berdasarkan data SKRT} tahun 2001 angka kematian ibu yang terbesar terjadi pada saat persalinan yaitu 44,7\%, saat kehamilan sebesar 28,9\%, dan yang terakhir adalah terjadi pada saat nifas yaitu 26,3\%. Angka kematian ibu tersebut disebabkan oleh beberapa faktor baik langsung maupun tidak langsung, penyebab langsung kematian ibu terbesar adalah komplikasi obsetrik (90\%) yang dikenal dengan Trias Klasik seperti perdarahan, infeksi, dan preeklamsi/eklamsi.

\section{Penyebab kematian tidak} langsung merupakan akar permasalahan dimana erat hubungan nya dengan sosial dan budaya seperti kebiasaan, kepercayaan, sikap dan prilaku masyarakat terhadap perawatan kehamilan dan persalinan sehingga mengakibatkan tingginya angka kesakitan dan kematian khususnya pada ibu. Tingginya angka kematian ibu di Indonesia merupakan salah satu indikasi dari lemahnya perlindungan terhadap hak reproduksi perempuan dimana memiliki kaitan dengan perawatan kehamilan dan persalinan, selain itu disebabkan oleh adanya faktor 3 Terlambat yaitu: 1) terlambat dalam mengenali tanda bahaya, 2) terlambat dalam mengambil keputusan, 3) terlambat di fasilitas kesehatan dalam memberikan pertolongan (Depkes RI, 2008).

Angka Kematian Ibu di Provinsi Banten pada tahun 2010 adalah 187,2 per 100.000 Kelahiran Hidup, adapun penyebab kematian terbesar di sebabkan oleh perdarahan, eklamsi dan infeksi, sementara pertolongan persalinan oleh tenaga kesehatan mencapai 79,32\% (Dinkes Prop. Banten, 2009). Jumlah kematian ibu di Kabupaten Lebak pada tahun 2011 adalah sebanyak 42 orang dari 28117 ibu yang melahirkan, adapun penyebab kematian Ibu adalah perdarahan 10 orang, hipertensi 
dalam kehamilan 8 orang, infeksi 2, partus lama 1 orang, lain-lain 21 orang (Dinkes Kab. Lebak, 2011).

Desa Kanekes terbagi menjadi dua bagian yaitu Baduy Luar dan Baduy Dalam. Jumlah kematian ibu di Desa Kanekes pada tahun 2011 yang tercatat oleh tenaga kesehatan adalah sebanyak 3 orang dari 182 orang ibu yang melahirkan. Penyebab kematian adalah perdarahan dan jumlah kematian bayi pada tahun yang sama adalah sebanyak 4 orang. Jumlah kematian ibu pada tahun 2012 adalah 2 orang dari 177 ibu yang melahirkan, penyebabnya adalah perdarahan Sedangkan tahun 2011 sampai tahun 2012 tidak ada kematian ibu jumlah kematian ibu di Baduy Dalam pada tahun 2009 berjumlah 1 orang dari 9 ibu yang melahirkan.

Tahun 2010 jumlah kematian ibu berjumlah 1 orang dari $8 \mathrm{ibu}$ yang melahikan, penyebab kematianya adalah perdarahan. Data kematian bayi dari tahun 2009 sampai 2011 tidak ada kematian bayi, dan pada tahun 2012 jumlah kematian bayi sebanyak 1 orang (Puskesmas Cisimeut, 2011).

Jika keadaan ini terus menerus dibiarkan dan tidak mendapat tanggapan dan perhatian yang serius dari instansi yang terkait maka akan memberikan dampak buruk terhadap derajat kesehatan dan peningkatan kematian pada ibu. Baduy Dalam merupakan masyarakat yang sangat sulit menerima berbagai pengaruh dari luar salah satunya tentang program kesehatan KIA (Kesehatan Ibu dan Anak), karena masih ada tradisi yang selalu dilakukan masyarakat Baduy Dalam khususnya tentang perawatan kehamilan dan persalinan, mereka masih menggunakan tenaga tradisional dukun paraji dengan menggunakan ramuan rempah dan mantra-mantra.

Hal itu disebabkan karena masyarakat Baduy Dalam masih menganut budaya yang diturunkan oleh leluhur mereka bahwa untuk melakukan pemeriksaan kehamilan dan pertolongan persalinan cukup ke dukun paraji, mereka menganggap bahwa kehamilan dan persalinan 
adalah sebagai fenomena alamiah atau wajar yang tidak memerlukan perhatian khusus dan pasrah menerima semua apa yang terjadi pada masa kehamilan dan persalinan karena semuanya didasarkan pada kehendak tuhan.

\section{Metode Penelitian}

Metode penelitian yang digunakan adalah metode qualitatif Pemilihan informan pada penelitian ini dilakukan dengan menggunakan teknik non probability sampling (sampel non probabilitas), salah satu teknik sampel non probabilitas adalah purposive sampling.Adapun informan utama dalam penelitian ini adalah bidan desa dan PTT yang pernah atau sedang bertugas didaerah baduy Dalam sebanyak 3 orang, informan sekunder terdiri dari $3 \mathrm{ibu}$ hamil, 3 ibu bersalin, 1 dukun / paraji dan 1 tokoh masyarakat di Baduy Dalam.

Data diperoleh melalui wawancara mendalam (in depth interview) bidan desa/PTT, ibu hamil, ibu bersalin, paraji dan tokoh masysarakat.. Analisis data dengan menggunakan metode content analysis (analysis isi) yaitu metode yang berusaha mengidentifikasi, menganalisis, dan melaporkan polapola yang ada berdasarkan data yang terkumpul, yaitu pengumpulan data, reduksi data, verifikasi kemudian disajikan dalam bentuk deskriptif, dengan mengikuti pola berpikir induktif, yaitu pengujian data yang bertitik tolak dari data yang telah terkumpul kemudian dilakukan penarikan kesimpulan (Sugiyono, 2011).

Penelitian ini dilakukan masyarakat Baduy Dalam Kabupaten Lebak, dengan informan utama bidan yang bertugas di Desa Kanekes khususnya masyarakat Baduy Dalam.

\section{Hasil}

\section{Gambaran Fasilitas dan Pelayanan Kesehatan di Masyarakat Baduy Dalam}

Hasil wawancara dengan informan utama penelitian mengatakan bahwa di Baduy Dalam tidak ada sarana pelayanan kesehatan untuk pemeriksaan ibu hamil dan bersalin seperti posyandu, polindes maupun 
poskesdas. Hal ini disebakan karena aturan adat melarang adanya bangunan yang bersifat modern.

\section{Norma dalam perawatan kehamilan.}

Di masyarakat Baduy Dalam tidak ada aturan khusus bagi ibu hamil untuk melakukan pemeriksaan hamil ke siapapun, namun mereka bila sedang hamil biasa memeriksakan kehamilannya ke dukun paraji. Aturan yang biasa dilakukan masyarakat Baduy Dalam terkait perawatan/pemeriksaan kehamilan pertama kali dilakukan setelah ibu merasa telat haid, selama 2-3 bulan, dan merasakan mualmual. Selanjutnya mereka datang ke paraji untuk diperiksa dan, setelah dinyatakan hamil maka paraji melakukan pemeriksaan hamil dengan cara diurut/digedogkeun pada bagian perut ibu.

Setelah umur kehamilan 5 bulan dilakukan upacara 5 bulanan nenden sepaheun yaitu upacara pembuatan pagar yang diberikan seorang kokolot lembur untuk menghindari ibu hamil dari gangguan roh halus.
Pemeriksaan selanjutnya dilakukan setelah umur kehamilan 7 bulan, pada pemeriksaan ini di pasang kendit dari benang di bagian perut ibu. Pada kendit tersebut di beri tumbal oleh paraji dan tokoh adat setempatdengan alasan sebagai tolak bala (menjaga dari pengaruh roh halus) agar kehamilanny berjalan lancar. Pemeriksaan selanjutnya tergantung dari kemauan ibu hamil itu sendiri.

\section{Norma pantangan yang harus dilakukan ibu hamil}

Kebiasaan pantangan yang biasa harus dilakukan oleh ibu hamil di Baduy Dalam yaitu tidak boleh minum air dan makanan yang masih panas, tidak boleh makan buah nanas, melilitkan handuk dileher, dilarang duduk di depan pintu, harus bisa menjaga sikap dan tingkah laku. Mereka meyakini apabila larangan itu dilakukan bisa membuat kehamilannya sehat dan melahirkan lancar. Hal ini karena aturan adat yang berlaku di Baduy Dalam

\section{Norma dalam pertolongan persalinan}


Di masyarakat Baduy Dalam ibu bersalin biasanya melahirkan secara mandiri yaitu dari mulai adanya tanda-tanda persalinan seperti terasa mules, keluar lendir bercampur darah sampai bayi dan plasenta lahir dibiarkan saja tanpa ada pendamping persalinan.

Setelah bayi dan plasenta lahir biasanya keluarga memanggil paraji, tugas paraji hanya melakukan perawatan bayi dan ibunya yaitu paraji memotong tali pusat dengan (hinis) tali pusat di ikat pakai benang teureup, bayi di mandikan, diolesi dengan kunyit supaya bersih dan tidak mudah terkena penyakit, tali pusat di beri kopi lalu ditutup dengan daun sirih supaya cepat kering dan puput. Ibu di urut perutnya, dimandikan dan disuruh nyanda selama 3 minggu, dengan alasan supaya peredaran darahnya lancer

\section{Norma pantangan yang harus di lakukan oleh ibu bersalin}

Pantangan yang harus dilakukan ibu bersalin yaitu ibu dan bayi tidak boleh bepergian jauh keluar rumah sebelum 40 hari setelah melahirkan, tidak boleh makan ikanikan yang bau amis agar tidak terjadi komplikasi. Hal ini karena adanya aturan adat yang mengikat mereka seperti itu, dan apabila melanggar aturan tersebut akan terjadi sesuatu yang buruk pada diri seseorang yang telah melanggar aturan itu

\section{Norma bagi yang melanggar aturan adat.}

Sanksi atau hukuman yang diberikan kepada orang yang telah melanggar aturan adat. Orang yang telah melanggar aturan adat biasanyamendapat sanksi hukuman selama 40 hari di tempat rumah tahanan yang sudah di sediakan (jaro daka) didaerah Baduy Luar.

\section{Dukungan Tokoh Masyarakat}

Dari hasil wawancara didapatkan bahwa tokoh masyarakat Baduy Dalam mau menerima dengan baik ketika ada kunjungan pelayanan kesehatan khususnya kegiatan pemeriksaan kehamilan dan pelayanan lainnya. Adapun bentuk dukungan yang diberikan oleh tokoh masyarakat Baduy Dalam terhadap 
kegiatan tersebut antara lain memfasilitasi tempat untuk pelayanan pemeriksaan kehamilan dan pelayanan yang lainnya, menyediakaan tempat untuk istirahat serta membantu menyiapkan dan mencari sasaran yang ada untuk bisa datang ke tempat pelayanan

\section{Sikap Bidan Terkait Budaya perawatan kehamilan dan persalinan}

Bidan bisa menerima budaya perawatan kehamilan dan persalinan di masyarakat Baduy Dalam selagi budaya tersebut tidak merugikan kesehatan. Bila ada yang bertentangan dengan kesehatan maka informan meminimalisir masalah tersebut dengan tidak merubah budaya yang ada.Hal ini dilakukan karena bidan sudah mengerti dan memahami budaya tersebut.

\section{Stategi bidan dalam memberikan pelayanan perawatan kehamilan dan persalinan}

Berdasarkan hasil wawancara bahwa strategi yang dilakukan bidan dalam memberikan perawatan kehamilan dan persalinan di masyarakat Baduy Dalam adalah pertama melakukan pendekatan kepada tokoh masyarakat dan menggerakan partisipasi masyarakat dengan melibatkan kepala keluarga khususnya suami.

Strategi kedua menjalin kemitraan bidan dengan paraji yang ada, strategi ketiga meningkatkan profesionalisme sebagai bidan dengan cara meningkatkan pendidikan ke jalur yang lebih tinggi, mengikuti pelatihan, seminar dengan tujuan untuk meningkatkan pengetahuan, strategi keempat yaitu mendirikan program imah pangubaran pusat informasi Baduy tanpa menghilangkan ciri khas Baduy nya, strategi kelima yaitu petugas kesehatan/bidan harus tinggal menetap di daerah Baduy. Strategi selanjutnya yaitu bidan bisa menerima dan menghormati budaya mereka apa adanya.

\section{Pembahasan}

\section{Gambaran fasilitas kesehatan}

Di masyarakat Baduy Dalam tidak ada fasilitas kesehatan seperti pustu, polindes, posyandu, ini disebabkan karena aturan adat 
melarang adanya bangunan yang bersifat modern. Menurut Eliot A (20013) dikatakan bahwa norma yang berlaku dimasyarakat sangat mempengaruhi prilaku kesehatan dari anggota masyarakat yang mendukung norma tersebut.

\section{Norma dalam perawatan} kehamilan

Pemeriksaan pertama dilakukan apabila ibu tidak haid selama beberapa bulan (2-3 bulan) datang ke parajidiperiksa, setelah dinyatakan hamil maka dilakukan pengurutan/digedogkeun pada perut ibu, setelah umur kehamilan 5 bulan dilakukan upacara lima bulanan (neundeun seupaheun) yaitu pembuatan pagar yang diberikan oleh kokolot lemburuntuk menghindari ibu dari gangguan roh dan marabahaya selama kehamilan.

$$
\text { Selanjutnya upacara tujuh }
$$

bulanan pemasangan kendit oleh kokolot lembur yang diberi jampejampe pemeriksaan selanjutnya umur kehamilan 9 bulan. Hal ini karena budaya, tradisi yang diwariskan dari nenek moyang dan harus mereka lalukan. Pantangan untuk ibu hamil di Baduy Dalam tidak boleh minum air dan makanan yang masih panas, buah nanas, melilitkan handuk dileher, menjaga sikap dan tingkah lakusupaya kehamilannya sehat dan melahirkan lancar. Apabila dilanggar menurut mereka akan terjadi sesuatu terhadap orang yang melanggar aturan tersebut. Menurut Notoatmodjo (2010) dikatakan bahwa norma yang berlaku di masyarakat sangat mempengaruhi prilaku kesehatan dari anggota masyarakat yang mendukung norma tersebut.

\section{Norma dalam pertolongan persalinan}

Proses persalinan di Baduy Dalam dilakukan sendiri tanpa bantuan orang lain dari ada tanda-tanda persalinan sampai bayi dan plasenta dibiarkan lahir dengan sendirinya tanpa pendamping persalinan. dengan cara menggunakan bengkung taerbuat dari kain merah berukuran panjang 5-7 meter lebar $20 \mathrm{~cm}$, diikatkan diatas pintu, ketika ada mules ibu 
mengedan memegang bengkung dengan kedua tangan dengan posisi sepertiga jongkok. Dibawah bokong ibu diletakan kain bersih setelah bayi dan plasenta lahir baru memanggil paraji untuk merawat bayinya.

Perawatan bayi dilakukan dengan cara tradisional yaitu memotong tali pusat dengan (hinis) tali pusat di ikat pakai benang teurup, di beri kopi lalu ditutup dengan daun sirih supaya cepat kering dan puput, badan diolesi dengan kunyit supaya bersih dan tidak mudah terkena penyakit. Norma untuk ibu bersalin dilarang memakan ikan yang berbau amis, telor karena takut terjadi komplikasi, ibu dan bayi tidak boleh bepergian jauh sebelum 40 hari karena aturan adat.Hal ini disebabkan karena kurangnya pengetahuan terhadap pentingnya persalinan oleh tenaga kesehatan dan aturan adat yang memikat. Menurut Bernet (2006) bahwa norma sosial merupakan suatu alat kendali atau batasan-batasan dalam berprilaku,
4. Norma Bagi yang melanggar adat

Masyarakat Baduy Dalam harus bisa mentaati semua aturan yang sudah ditetapkan apabila ada yang melanggar aturan tersebut maka orang yang bersangkutan akan mendapat hukuman selama 40 hari ditempat yang sudah ditetapkan yaitu di Baduy Luar (tempat jaro daka).

Setelah selesai masa hukuman maka orang tersebut diharuskan melalukan acara ritual pembersihan diri untuk menghapus dosa yang telah dilakukan, kemudian setelah selesai acara pembersihan diri orang tersebut diperbolehkan kembali untuk masuk ke baduy dalam. Pernyataan ini sejalan dengan penelitian Salamah.T (2012) dan menurut Kurnia A (2010) bahwa apabila ada yang melanggar aturan adat, maka orang yang melanggar akan mendapat hukuman selama 40 hari di baduy luar. Menurut Daeng $\mathbf{H}$ (2000) dikatakan bahwa norma sosial merupakan suatu alat kendali atau batasan-batasan dalam berprilaku, pada umumnya 
pelanggaran sosial yang berlaku bukan karena seseorang takut pada sesamanya, akan tetapi keyakinan bahwa perbuatan melanggar norma itu adalah aib dan merugikan bagi dirinya

\section{Dukungan Tokoh Masyarakat}

Kegiatan pemeriksaan kehamilan dan pertolongan persalinan yang selama ini diberikan kepada masyarakat Baduy Dalam telah mendapatkan dukungan dari tokoh masyarakat (puun). Bentuk dukungannya setiap ada kegiatan pelayanan kesehatan khususnya pemeriksaan kehamilan tokoh masyarakat memberitahukan kepada masyarakat tentang rencana kegiatan yang akan dilakukan di Baduy Dalam agar bisa datang pada kegiatan pelayanan tersebut, menyediakan tempat untuk pelayanan kegiatan dan tempat untuk istirahat para petugas.

(1999) dikatakan bahwa untuk berprilaku sehat, kadang-kadang masyarakat bukan hanya perlu pengetahuan dan sikap positif dan dukungan fasilitas saja, melainkan diperlukan dukungan dan prilaku contoh (acuan) dari pada tokoh masyarakat, tokoh agama.

\section{Sikap bidan terkait budaya perawatan kehamilan dan persalinan}

Bidan bisa menerima budaya perawatan kehamilan dan persalinan yang berlaku di Baduy Dalam, selagi tidak merugikan kesehatan dan menerima mereka apa adanya. Jika merugikan kesehatan upaya yang dilakukan meminimalisir masalah tersebut dengan tidak merubah budaya yang ada, berusaha untuk ikut serta dalam kegiatan yang biasa masyarakat lakukan seperti perayaan upacara adat yang biasa rutin dilakukan. Hal itu karena bidan sudah memahami budaya tersebut. Menurut Alexandra. I (2010) Jika tenaga kesehatan ditugaskan didaerah yang masyarakatnya masih memegang teguh adat untuk menghindari pertentangan tenaga kesehatan harus berupaya menghormati adat masyarakat setempat, menerima masyarakat apa adanya dan hati- hati dalam memperkenalkan nilai-nilai yang 
baru. Menurut Turner (2009) seseorang yang memasuki tempat yang baru berlatar belakang budaya yang berbeda secara sadar maupun tidak sadar akan aktif mencari informasi mengenai budaya di lingkungan baru.

\section{Strategi bidan dalam memberikan pelayanan perawatan kehamilan dan persalinan}

Strategi bidan dalam memberikan pelayanan perawatan kehamilan dan persalinan di masyarakat Baduy Dalam yaitu pertama melakukan pendekatan kepada tokoh masyarakat Baduy Dalam dan menggerakan partisipasi masyarakat dengan melibatkan kepala keluarga khususnya suami. Hal ini dilakukan karena bidan mengetahui dan memahami bahwa di Baduy dalam pengaruh tokoh adat sangat kuat dan masih menganut pola paternalistik karena asumsi masyarakat Baduy Dalam bahwa kepala keluarga itu mempunyai tanggung jawab yang besar dan harus mengetahui semua hal termasuk masalah kesehatan. Menurut
Notoadtmojo (2007) untuk keberhasilan program kesehatan diperlukan dukungan sosial yaitu dukungan dari tokoh masyarakat dan peran serta masyarakat dengan tujuan tokoh masyarakat sebagai jembatan antara sektor kesehatan sebagai pelaksana program kesehatan dengan masyarakat sebagai penerima program.

Sehingga tokoh masyarakat bisa mensosialisasikan programprogram kesehatan agar masyarakat mau menerima dan berpartisifasi terhadap program kesehatan tersebut. Strategi kedua menjalin kemitraan bidan dengan paraji, Hal ini dilakukan karena bidan memahami bahwa masyarakat Baduy Dalam masih memegang teguh adat, danmenaruh kepercayaan yang besar kepada dukun paraji sehingga kemitraan bidan dengan dukun paraji perlu dilaksanakan untuk meningkatkan akses dan kualitas pelayanan kesehatan ibu dan bayi baru lahir oleh tenaga kesehatan.

Bentuk kegiatan yang dilakukan bidan yaitu memberikan bimbingan kepada dukun paraji cara menerapkan teknik antiseptik yang 
harus dilakukan dukun paraji pada saat menolong persalinan dan melakukan perawatan bayi baru lahir dengan tidak menghilangkan budaya yang ada. Menurut Depkes (2008) untuk mendapatkan suatu tujuan bersama dalam bidang kesehatan dibutuhkan suatu kerja sama atau kemitraan, salah satunya kemitraan bidan dan paraji dengan tujuan untuk meningkatkan akses ibu dan bayi terhadap pelayanan kesehatan yang berkualitas

\section{Strategi}

ketiga

Meningkatkan profesionalisme sebagai bidan dengan cara meningkatkan pendidikan ke jalur yang lebih tinggi, mengikuti pelatihan, seminar dengan tujuan untuk meningkatkan pengetahuan. Hal ini dilakukan agar bidan bisa meningkatkan pengetahuan dan pemahaman tentang budaya serta bagaimana strategi dalam memberikanpelayanan kesehatan khususnya perawatan kehamilan dan persalinan.

Penyataan ini sejalan dengan Djoko.H (1999) bahwa untuk melaksanakan tugasnya dengan baik maka tenaga kesehatan perlu dibekali pengetahuan yang cukup melaui pendidikan formal maupun informal, serta pengetahuan terhadap pemahaman budaya lokal khususnya dalam kaitannya dengan program kesehatan reproduksi. Dan menurut Notoatmodjo (2005) tingkat pendidikan sangat berpengaruh terhadap pengetahuan khususnya dalam pembentukan prilaku, semakin tinggi tingkat pendidikan seseorang maka semakin matang dalam pertimbangan seseorang untuk bertindak dalam mengambil keputusan.

\section{Startegi}

\section{keempat}

mendirikan program "imah pangubaran" pusat informasi Baduy artinya membuat tempat untuk pelayanan kesehatan yang bentuknya seperti asli rumah Baduy agar masyarakat Baduy Dalam tidak merasa asing dengan tempat tersebut - Program ini sebagai program pemberdayaan bidang kesehatan yang merupakan gagasan dari bidan,warga Baduyyang bekerja sama dengan donatur yayasan Nurani dunia. Hal ini dilakukan karena bidan memahami bahwa tokoh masyarakat di Baduy Dalam 
melarang adanya fasilitas modern karena bertentangan dengan aturan adat yang ada, Alasan lain yaitu untuk menghindari adanya pelanggaran terhadap aturan adat. Menurut Haning D (2000) salah satu upaya yang mungkin dilakukan untuk mendekatkan pelayanan kesehatan adalah dengan membangun fasilitas kesehatan yang dekat dengan pemukiman penduduk misalnya dengan membangun semacam rumah tunggu atau yang belakangan populer dengan sebutan pondok sayang ibu. Dan menurut Atik P (2010) faktor yang bisa mendukung seseorang untuk berprilaku salah satunya tersedianya sarana, fasilitas, yang mengfasilitasi terjadinya prilaku seseorang.

Strategi kelima petugas kesehatan/bidan harus tinggal menetap didaerah Baduy. Hal ini dilakukan karena bidan memahami bahwa masyarakat Baduy Dalam sangat sulit menerima dan bisa berinteraksi dengan orang baru, sehingga dibutuhkan waktu yang cukup lama untuk melakukan pendekatan dengan mereka dan bisa mengenal lebih jauh tentang budaya perawatan kehamilan dan persalinan.

Menurut Rejeki, S (20013) bahwa seorang yang memasuki tempat yang baru berlatar belakang budaya yang berbeda secara sadarmaupun tidak sadar akan aktif mencari informasi mengenai budaya di lingkungan baru dan mau tinggal menetap didaerah tersebut untuk meningkatkan interaksi.Strategi selanjutnya yaitu bidan harus bisa menerima dan menghormati budaya yang ada.

Hal ini dilakukan karena bidan sudah mengetahui bahwa budaya perawatan kehamilan dan persalinan di Baduy Dalam sulit sekali untuk dirubah, untuk bisa berinteraksi dengan mereka bidan harus berusaha memahami dan bisa menerima mereka apa adanya. Menurut Ide Alexandra (2012) Jika tenaga kesehatan ditugaskan didaerah yang masyarakatnya masih memegang teguh adat untuk menghindari pertentangan tenaga kesehatan harus berupaya menghormati adat masyarakat setempat, menerima masyarakat setempat apa adanya dan hati- hati 
dalam memperkenalkan nilai-nilai yang baru.

\section{Simpulan dan Saran}

1. DiBaduy Dalam tidak ada fasilitas kesehatan karena tidak memperbolehkan adanya sarana yang modern

2. Perawatan kehamilan dan pertolongan persalinan di masyarakat Baduy Dalam masih dilakukan secara tradisional sesuai aturan adat yang ada.

3. Norma bagi yang melanggar adat di kenakan hukuman selama 40 hari

4. Bidan menerima budaya perawatan kehamilan dan persalinan di Baduy Dalam selagi budaya tersebut tidak merugikan kesehatan. Bila ada yang bertentangan dengan kesehatan maka meminimalisir masalah tersebut dengan tidak merubah budaya yang ada

5. Pada prinsipnya tokoh masyarakat Baduy Dalam menerima terhadap kegiatan pelayanan kesehatan yang diberikan oleh bidan asal tidak melanggar aturan adat yang ada.

6. Strategi yang dilakukan bidan dalam memberikan perawatan kehamilan dan persalinan yaitu melakukan pendekatan kepada masyarakat dan tokoh masyarakat Baduy Dalam, menjalin kemitraan bidan dengan paraji yang ada, menggerakan partisipasi masyarakat, meningkatkan profesionalisme sebagai bidan. Mendirikan program imah pangubaran pusat informasi Baduy, bidan bersedia tinggal di daerah Baduy untuk beradaptasi,bidan harus menerima dan menghormati budaya setempat.

7. Untuk memudahkan jangkauan pelayanan kesehatan agar di bangun sarana rumah tunggu dilengkapai dengan peralatan kesehatan tanpa menghilangkan ciri khas dari budaya Baduynya.

8. Untuk mengurangi terjadinya komplikasi yang terjadi pada kehamilan dan persalinan perlu dilakukan pelatihan pada dukun paraji tanpa menghilangkan budaya aslinya. 
Daftar Pustaka

Amri Zami. 2002. Buku kuliah Kesehatan Reproduksi. Jakarta.

Alexandra. I. 2012 Sosiologi Kebidanan. Rona panca Ilmu. Yogyakarta.

Atik P. 2010. Ilmu Kesehatan Masyarakat dalam Kontek Kebidanan. ECG. Jakarta.

Awawa M. 2010 teori dan pengukuran pengetahuan, sikap dan prilaku manusia, Nuha Medica. Yogyakarta.

Bertens K. 2006 Etika. Pustaka utama Jakarta.

Bungin B. 2005. Analisis Data Penelitian kualitatif. Raja grafindo persada.

Bungin B. 2007. Penelitian Kualitatif. Pranata media Group.

Daeng H. 2000. Manusia, Kebudayaan dan Lingkungan Tinjauan antropologis. Pustaka Pelajar. Yogyakarta.

Depkes RI. 2005. Strategi Akselerasi Pencapian target MDG'S 2015. Jakarta.

Depkes RI. 2008. Pedoman Program Perencanaan dan Pencegahan Stiker dalam Rangka Mempercepat penurunan AKI. Departemen Kesehatan. Jakarta.

Depkes RI. 2008. Modul Pelatihan Bidan poskesdes dalam Pengembangan Desa Siaga.
Departemen Kesehatan Republik Indonesia.

2008. Asuhan Persalinan Normal jaringan nasional Pelatihan klinik kesehatan Reproduksi. Departemen Kesehatan Republik Indonesia. 2008. Pedoman Kemitraan Bidan dengan Dukun .Direktorat Jenderal Bina Kesehatan Masyarakat. Jakarta.

Perencanaan Persalinan, proyek kesehatan perempuan dan Kesejahteraan Keluarga. Badan Pembangunan Nasional. Jakarta.

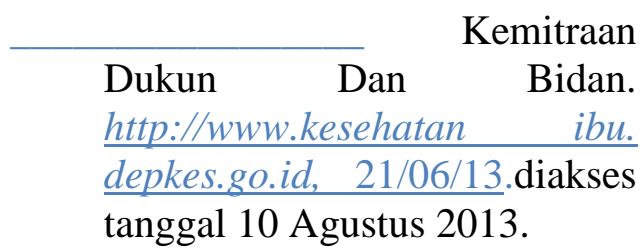

Dinkes Prop. Banten. 2009. Propil Kesehatan Provinsi Banten.

Dinkes Kab. Lebak. 2011. Laporan bulanan program KIA .

Eliot A. Adaptasi Budaya http://.id.wikipedia.org/ wiki. diunduh tanggal 29 September 2013 jam $20{ }^{00} \mathrm{WIB}$

Green LW. 2000. Health Promotion Planning An Educational and Environmental Approach. USA: Mayfield Publishing Company.

Hartono J dkk. 1999. Akses Terhadap Pelayanan Kesehatan Reproduksi Study Kasus di Kabupaten Jayawijaya. Irian Jaya. 
Indrawarsih R. 2012. Strategi Sosial Budaya Dalam Adaptasi Lingkungan. Lembaga IPI.

Ide A. 2012.Sosiologi Kebidanan. Rona panca Ilmu.Yogyakarta.

Koentjaraningrat. 2001. Manusia dan kebudayaan di Indonesia. Djambatan. Jakarta.

Kurnia A\& dkk.2010. Saatnya baduy bicara. Bumi Aksara.

Muhamad B. 1999. Pokok-pokok hukum Adat.Pradnya paramita Jakarta.

Notoatmodjo S. 2005.Pendidikan dan Prilaku Kesehatan. Rineka Cipta. Jakarta.

$\begin{array}{llr} & 2007 & \text { Promosi } \\ \text { kesehatan } & \text { Dan } & \text { Ilmu }\end{array}$
Prilaku.Rineka Cipta. Jakarta. 2009. Ilmu prilaku Kesehatan. Rineka Cipta. Jakarta.

\begin{tabular}{lr} 
& \\
\hline prilaku Kesehatan. & Rineka \\
Cipta. Jakarta. &
\end{tabular}
2010. Metode Penelitian Kesehatan. Rineka Cipta. Jakarta.

\begin{tabular}{lcr} 
& 2012. & Promosi \\
\hline kesehatan & teori & dan \\
Aplikasinya. & Rineka & cipta. \\
Jakarta. & &
\end{tabular}

Noorkasiani P. 2012. Sosiologi Kebidanan. Jakarta.

Puskesmas Cisimeut. Propil Puskesmas Cisimeut. 2011.

bulanan program KIA. 2011.
Sarwono S. 1997. Sosiologi Kesehatan Beberapa Konsep Beserta Aplikasinya. Gajah Mada University Press. Yogyakarta.

Sri Rejeki Ninik Adaptasi Antarbudaya. http://jurnal. uajy.ac.id/jik/files/2012/05/3.MC-145-166. diunduh tanggal 23 September 20013 jam 21.00 WIB.

Satori D, Komariah A. 2010. Metodologi Penelitian Kualitatif. Alfabeta. Bandung.

Soemardjan S. 2001.Setangkai Bunga Sosiologi. UI Jakarta.

Sugiyono.2011. Metode penelitian Kuantitatif. Rineka Cipta. Jakarta.

Sumiyati dkk. 2006. Perawatan ibu hamil. Fitramaya Yogyakarta.

Thomasita S. 2012.Aspek Sosial Budaya mempengaruhi kematian ibu pada masa kehamilan dan kelahhiran. Tesis.

Tuner A. 2009. DasarDasar Komunikasi Antar budaya. Pustaka Pelajar. Yogyakarta.

Yuni K \& dkk. 2009. Perawatan Ibu Hamil . Yogyakarta. 